\title{
American War in Iraq: A Postcolonial Ecocritical Reading of Selected Poems by Brian Turner
}

الباحث/ شريف عبد الحميد حامد بهوتي

$$
\begin{aligned}
& \text { الحرب الأمريكية في العراق } \\
& \text { قراءة نقد بيئية بعد استعمارية في قصائد مختارة لبراين ترنر }
\end{aligned}
$$

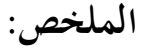

يهدف البحث بصفة أساسية إلي تطبيق النقد البيئي بعد الإستعماري علي قصائد مختارة

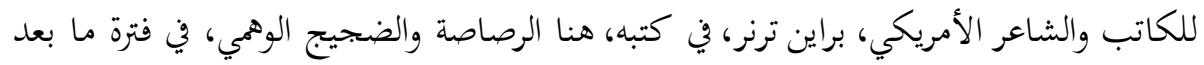

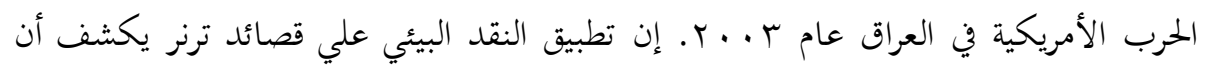

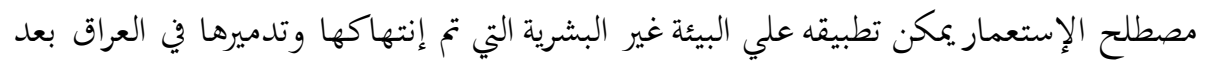



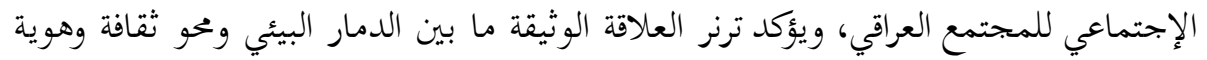

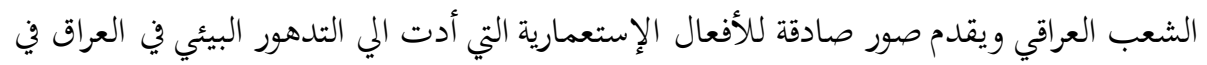

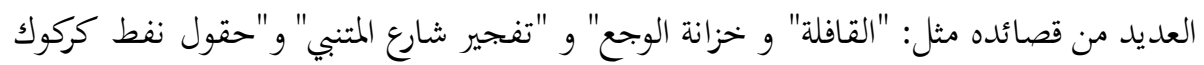

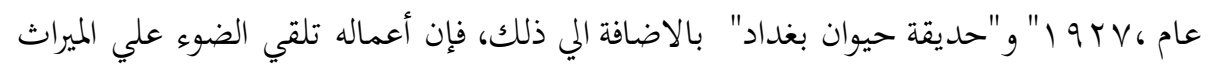

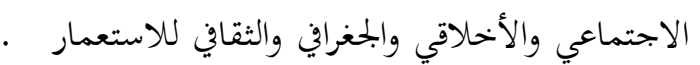

\section{Abstract}

The paper basically aims to apply postcolonial ecocriticism to selected poems of American writer and poet, Brian Turner, in his books, Here, Bullet and Phantom Noise after the 2003 American War in Iraq. Applying ecocriticism to Turner's poems reveals that the concept of colonization can be applied to non- human nature which has been 
violated and devastated in Iraq after war. Moreover, Turner's works emphasize the linkage between the ecological decay and the social decadence of the Iraqi society. Turner confirms the interrelatedness between the ecological destruction and the eradication of Iraqis' culture and identity. He presents the truthful images of the imperial actions that have led to the environmental deterioration in Iraq in many poems, such as "Caravan," "The Hurt Locker," "The Mutanabii Street Bombing," "Kirkuk Oilfield, 1927" and "The Baghdad Zoo." In addition, his works shed light upon the social, moral, geographical and cultural legacy of colonialism.

In most of his poems, Turner depicts the Iraqi landscape as a victim of the negative actions of colonizers. He proves that the Iraqi environment has been distorted, containing nothing valuable. He notes: "Nothing but bullets and pain. / and the bled-out slumping / and all the fucks and goddamns" ("The Hurt Locker," 2-4). Thus, the peaceful and fruitful status of environment has degraded and transformed into a barren and desolate one. It is always intertwined with ruin and death. Turner says: "Speak the word for death, Maut, / and you will hear the cursives of the wind / driven into the veil of the unknown" ("A Soldier's Arabic," 9-11). Moreover, Turner claims that the Iraqi landscape has become a means of killing and destruction, as represented in a quotation from his book My Life as a foreign Country while narrating his experience of invading Iraq: 
Our battle space-and perhaps it's a cliché now-will occur in a 360-degree, three-dimensional environment. When we entered this desert, the available calculus involved in the creation of any new moment changed. Anything is possible. A dead farm animal on the shoulder of the road could harbor an improvised bomb sewn into its belly. A bullet might ride the cool currents between one human being and another. A hellcat missile or a TOW missile might rend the moment open (16).

Therefore, it can be deduced that Turner underlines the importance of the desert as a figurative symbolism of the spiritual, historical and ideological authenticity of the nation. The truth of the bombs implanted into the bodies of the dead animals, flying bullets and the explosive missiles in the desert lay emphasis on the deterioration and eradication of the wildlife of the Iraqi environment. Moreover, Turner reconfirms the value of the desert on the cover of Here, Bullet. He captured himself as a solider standing alone in the midst of the Iraqi desert. The image of Turner, as a white soldier in the absence of the natives, symbolizes the hegemony of the colonizing forces on the Iraqi desert which represents the geographical, religious and cultural heritage of the Iraqi people.

In his poem, "Caravan," Turner presents an overview of the plunder and exploitation of the Iraqi land and its natural resources by colonizing troops. In one of the articles about 
the Iraqi War which sheds light on the U.S. imperial ambitions, Bullent Gokay confirms the importance of oil in forming U.S. global supremacy. He mentions that this interest has begun since the late 1940s. He continues: "that oil is part of a general strategy to maintain and exercise global power, and it's a central part of the US-centered global system." Therefore, "Middle Eastern oil has played a central role in the rise and continuation of the supremacy of the US and its close allies, arguably the central geopolitical story of our times." Gokay also adds that US tends to control the "global oil spigot" to immune any "competition for the top position in this inter-state hierarchy, as all the US's competitors are heavily dependent on Middle East oil."

In the initial lines of his poem, Turner aims to bring about a rapprochement with the Iraqi people. He tends to reinforce their culture by quoting an old Iraqi proverb. Then, he presents the vivid images of the tools of death and destruction the colonizing forces have brought to the people of the Middle East. These tools are represented in 'the boxes of death' that are full of the lethal weapons and bullets, in addition to some domestic things which are necessary for the survival of soldiers, including the huge quantities of toilet paper, insecticides and light bulbs:

No matter the barking of the dogs

the Caravan marches on.

-Old Iraqi Proverb 
A long queue of container ships

stand at anchor in the Persian Gulf.

They carry 50 caliber machine guns

in packing grease, dunnage, ammo crates,

millions of bullets laid side by side,

toilet paper, insecticides, light bulbs.

The dockside floodlights hum

with mosquitos and malaria ... (1-11)

In the preceding lines, it can be argued that these boxes of the colonizing troops symbolize much more than the tools of ruin and destruction. These boxes signify what is called 'invasive species,' which is non-native and destructive to the original environment of Iraq. In addition, it contributes to the distortion of the identity of the Iraqi people. Turner shifts to portray the Iraqi environment as devastated, polluted, and full of "mosquitos" and "malaria." That is a clear sign that the Iraqi people have been killed and threatened by the epidemic diseases and starvation as a result of the American occupation and international economic sanctions. These degrading conditions of Iraq pay no attention to the colonizing forces. They are absorbed in exploiting the land and its natural resources to gain their economic profits and secure their needs. Thus, the basic aim of colonizing troops is "the economic privilege" that has previously been described by Memmi as "the heart of the colonial relationship" (8). Turner alludes to that fact, depicting the American army as "an army of commerce" (19). He also refers to that meaning in his 
emphasis on the soldiers' plans for staying a long time in the region of the Middle East "where one earns more and spends less" (48) in Memmi's words. Turner continues:

... Cranes

hoist connexes onto flatbed trucks

which line Highway 1 from Kuwait City

to Dohuk in the north, just south of Turkey.

Try to imagine enough boxes of food

for one hundred and thirty thousand meals, two to three times a day, for a year.

It is an army of commerce, a fleet

of corporations with the Pacific as its highway.

It is around-the-clock, and it is every day.

These are the boxes we bring to Iraq.

And Iraq?

Today, in Baghdad, a bomb

killed 47 and wounded over one hundred.

it left a crater 10 feet deep. The stunned

gathered body parts from the roadway

and collected them in cardboard boxes. (12-28)

In the preceding lines, Turner uses visual imagery in his depiction of the scenes of horrible death and destruction of the Iraqi people and their occupied land. Turner portrays a tragic day in the life of Iraqis that evoke a sense of anguish and pity. A number of civilians have been killed and injured; some of them have been torn to shreds by the explosive remnants of war. Turner also explores the notions of 
environmental devastation, including the Iraqi infrastructure that has severely been damaged. Turner gives a hint to the interconnected and interchangeable relations between the conquered people of Iraq and their devastated land. Therefore, Iraqis have become humiliated and disempowered due to the fact that "the centralization or devolution of power is connected to the spaces which people live and act" (Nelson).

Crucially important, Turner confirms the concepts of 'environmental racism' and 'colonialist's environmental superiority.' He presents two contradictory images: the first image is the American soldier who cannot survive in his colony without modern weapons, insecticide and junk food made in his country. These images reflect the affluence of materialism and luxury. The second image is the Iraqi man who fights for his life, inhabiting among deadly insects, diseases, bombs and the holes in streets. Turner continues:

Imagine taping those boxes and shipping them home, to Washington, D. C., to the White House Lawn,

to bury them under the green sod thrown over, box by box emptied into that rich soil in silence, a Marine sentry standing guard as boxes are lowered into the ground nearby at the National Monument, Tomb of the Unknown, (29-35) 
In the preceding lines, Turner emphasizes the environmental injustice between the Iraqi and American people. He goes further to clarify the widening abyss between the exploited lands of Iraq and the civilized lands of the United States which are green, stable, peaceful and rich in its valuable resources. Turner politically taunts the U.S. invasion of Iraq and the lack of reverence for the Iraqi victims who go in vain. He calls for the reciprocal relationship between his country and the Iraqi people. Unfortunately then, Turner realizes that US would not care about these victims. They will not be transported to the "White House Lawn" to be buried under "the green sod" and the "rich soil." In addition, "Marines" will not guard their bodies nearby the "Tomb of the Unknown" at "the National Monument" because of the negative racial stereotypes of the Arabs as being uncivilized or barbaric. At the end of his poem, Turner continues to criticize the foreign policy of his country. He cynically refutes its claims of bringing justice and liberty to Iraq, demanding the American people to share the sufferings of Iraqis: "our own land given to these, / to say if this is freedom, then we will share it" (36-37).

In "Kirkuk Oilfield, 1927," Turner writes about the influence of petroleum industry in bringing about conflicts. Notably, his reference to Kirkuk oilfields gains its importance as they are considered one of the oldest and biggest oilfields in the region of the Middle East. Besides, US considers Kirkuk a repository of saving global shortfall in oil supply. In his 
poem, Turner uses a skilful simile in his concentration on the high economic power of Iraq offered by its oil reserves. He compares the image of the river flooded with oil to the image of heavy and prolonged bleeding that results from striking "a vein deep in the skull of God." He says:

We live on the roof of Hell, he says,

and Ahmad believes it, he's watched the gas flares

rise from holes in the earth, he's seen the black river

wash through the village in a flood of oil

as if the drillers had struck a vein

deep in the skull of God, [. . .] (1-6)

In Turner's next lines: "and the old man says / Boy, you must learn how to drive here" (6-7), he refers to the moral danger evoked by the ethnic conflicting ownership of the petroleum resources between Iraqis and Americans or between Iraqis themselves. Accordingly, Turner presents interdisciplinary relations between social and ecological issues, emphasizing his moral sense of ecology. He resists the economic and environmental devastation led by global capitalism. Turner further emphasizes the need for 'environmental justice,' which has previously been announced by Adamson et al:

The disproportionate incidents of environmental contamination in communities of poor and / or communities of color, to secure for those affected the right to live unthreatened by the risks posed by environmental degradation and contamination, and to afford equal access to 
natural resources that sustain life and culture (qtd. in Mukherjee 46).

Emphasizing these principles, Turner pays attention to the Iraqis' survival for an environmentally sustainable society. He warns the exploiters against the depletion of the natural resources of Iraqis as they can sacrifice themselves for the substance of their community. Turner's metaphor of "the dead are buried deep in the mind of God" indicates to the human and moral lessons derived from the Iraqis' struggle for social justice and liberty as Turner notes:

[. . .] and the old man says

Boy, you must learn how to drive here-

where the dead are buried deep in the mind

of God, manifest in man and woman,

given to earth in dark blood,

given to earth in fire. (6-11)

Turner writes his poem "Ashbah" in a melancholy mode of despair. He starts with the word "ghosts" in the first line to denote his loss of vision and hallucination as a result of war. Turner characterizes the slaughtered American soldiers as being victims of illegal war. They are lost and helpless, seeking for a shelter in the streets of the Iraqi town, "Balad". The natural setting of the poem, as represented in the scene of the desert and the sound of wind through "narrow alleys," refers to Turner's actual experience and imaginary one. Turner's usage of the words "desert," "trash" and "narrow 
alleys" implies the barrenness, dissolution and devastation of the Iraqi landscape as a result of being colonized. Turner gives a hint to the desert to emphasize its strong overtones to spirituality, identity, and religion of the Iraqi people. Again, the image of darkness is intertwined with the scene to increase the bleakness and mournfulness of the ruined landscape. That image indicates to the souls of American soldiers being tortured because of their participation in that war. Turner depicts the Islamic call to prayer as "soulful." He imaginatively perceives it as a sound of scolding and rebuke to the soldiers, reminding them of their terrible conditions:

The ghosts of American soldiers

wander the streets of Balad by night, unsure of their way home, exhausted, the desert wind blowing trash down the narrow alleys as a voice sounds from the minaret, a soulful call reminding them how alone they are, how lost. [...] (1-8)

In the following lines, Turner captures the painful images of the bodies of the Iraqi victims who are watched from rooftops. "Silence" signifies the deep grief of Iraqis on their country that has awfully been wrecked. The combination of both phrases of "ghosts of American soldiers," and "the Iraqi dead" suggest Turner's emphasis that war is destructive to both sides. The phrases also prove the harsh reality of man's inhumanity to man: 
[...] And the Iraqi dead,

they watch in silence from rooftops

as date palms line the shore in silhouette,

leaning toward Mecca when the dawn wind blows. (912)

In the preceding lines, Turner's mimicry and linguistic hybridity are obvious in his usage of the Arabic words derived from the Iraqi environment like "Ashbah," "Balad" and "date palms." Turner also uses the Islamic words and symbols like " minaret," "Mecca" and "a soulful call." His style demonstrates his deep spiritual significance for Muslims. It refers to his interconnected relations with the Arabic Islamic culture and heritage. Moreover, he tends to reinforce the Arabic and Iraqi identity. It can be argued that his usage of such Islamic symbols can indicate to the ideological reasons that lie behind the occupation of Iraq.

To refute Turner's claims of defending the Iraqi people and their rights against the American invasion, Turner is accused of colonial bias against Iraqis. Sinan Anton criticizes Turner's "Ashbah" as for him, "those who kill and those who are killed are equal in terms of victimhood." In other words, Turner does not differentiate between the American culprits and Iraqi victims.

In "The Hurt Locker," Turner urges his readers to open the hurt locker to release him and his comrades from their emotional and physical pain. The title of that poem has its 
private story as clearly apparent in Turner's article entitled "Home Fires: The Bomb within us." He notes:

In the summer of 2004 (while I was still in Iraq) I wrote a poem called "The Hurt Locker"-it appeared in my book, "Here, Bullet," published in 2005. I'd first heard the phrase (which means, in a broad sense, a private place of pain) when my squad leader turned to me and voiced his frustration with so many indirect attacks on us (mortar attacks, roadside bombs, snipers, etc.) sometimes I just want to put them in the hurt locker. It was a bizarre phrase that stuck with me for about two weeks before I wrote the poem.

Thus, in his poem, Turner explores the deteriorating conditions of the Iraqi society and the worst agonies of war for both the Iraqi people and colonizing forces:

Nothing but hurt left here

Nothing but bullets and pain.

and the bled-out slumping

and all the fucks and goddamns

and Jesus Christs of the wounded

Nothing left here but the hurt. (1-6)

Turner, in his poem, screams with terror and pain. His hurt locker is full of "fucks," "goddamns," and the wounds that are similar to the Passion of the Christ. Turner's usage of anaphora by repeating the word "nothing" implies that there are no valuable resources to be used in that desecrated land. That is due to the lack of moral ecology of the colonizing 
troops as they transgress the moral, legal and sociable values, thereby causing the bleakness and desolation of the Iraqi ecosystem. Turner's repetition of the word "hurt," refers to the spiritual and physical destruction because of the violence unleashed by colonizers against Iraqi landscape and its inhabitants. He uses harsh words like "bleed-out," "slumping," "fucks" and "goddamns" to make reference to the feelings of Iraqis' despair, resentment and condemnation of war:

Believe it when you see it

Believe it when a twelve-year-old

rolls a grenade into the room.

Or when a sniper punches a hole

deep into someone's skull.

Believe it when four men

step from a taxicab in Mosul

to shower the street in brass

and fire. $[\ldots] \quad(7-15)$

In the preceding lines, the negative feelings of Iraqi people are transformed into revenge attacks against the presence of the invading forces. Thus, Turner alludes to the political, moral and psychological impacts of the ecological decay on the moral disintegration and social decadence of the Iraqi society, as represented in the behaviors of teenagers who are involved in gang wars. They defend their land, carrying grenades while others snipe at the American soldiers, causing deep holes in their skulls. 
Turner expresses Iraqis' acts of resistance against the military occupation. He depicts the images of the men coming from a mile away to commit intense indiscriminate attacks against the invading troops. Then, he reaches to a striking image: "to shower the street in brass and fire" (14-15). That image is an implied metaphor denoting the awful conditions of the Iraqi infrastructure in addition to the lack of physical and spiritual interaction between the Iraqi people and their environment.

To elaborate, it can be argued that Turner's works reflect his social ecology. There is a linkage between Turner's ecological approach and the decay of the Iraqi society. His approach is earlier supported and defined by Paul Lindholdt as 'bio-regionalism' that is the process of rediscovering human connections to the land" (qtd. in Mukherjee 44). That bioregional approach is also described by Kern as: "the fundamental shift from one context of reading to anothermore specifically, a movement from the human to the environmental, or at least from the exclusively human to the biocentric or ecocentric, which is to say a humanism . . . informed by the awareness of the "more-than-human" (44).

In reference to the poem, Turner reiterates the phrase, "believe it," many times to urge the reader to perceive the monstrosity of war. Turner strongly recommends his readers to look that hurt locker up and down to see the remnants of human bodies, as represented in "teeth" and harmful weapons like "knives" which imply killing and destruction. Turner 
wishes that human beings benefit from his experience; the human race should realize the cruelty of war in which you or your comrades may be brutally murdered without mercy:

[...] Open the hurt locker

and see what there is of knives

and teeth. Open the hurt locker and learn

how rough men come hunting for souls. (16-19)

In "What Every Solider Should Know," Turner starts with the second-person pronoun, distancing himself from the racial prejudice and implicating the reader in it. He describes the terrible moments of every American soldier who encounters murder at the hands of Iraqis who resist occupation. The identity of the addressee is anonymous as it conveys a hidden implication that any solider involved in the war has to bear its terrible consequences. Turner presents the images of two contradictory connotations: the celebration of mundane and the atmosphere of rural and peaceful tranquility that are intertwined with the harbinger of death and brutal murder. Interestingly, Turner's cultural and linguistic hybridity, that is sparked at one climatic point, works out the new perspectives on recognizing the Arabic and Islamic culture and identity:

If you hear gunfire on a Thursday afternoon It could be for a wedding, or it could be for you

Always enter a home with your right foot; the left is for cemeteries and unclean places. 
$\mathrm{O}$-guf! Tera armeek is rarely useful.

It means Stop! Or I'll shoot. (3-8)

Turner continues to depict the horrible conditions of the American soldiers who have been in agony of being assassinated. The cycle of violence and counter violence between the opposing sides has led to the crippling of the basic civil services and infrastructure. That ruin is represented in the "bombs under the overpasses and in cars" (13-14). Environmental ruin extends to the domestic things that are devoted to the construction industry and safety like "trashpiles" and "bricks" (13-14). Therefore, the objects of the Iraqi infrastructure have been distorted, becoming a powerful means of killing to the colonizing forces and the Iraqi people. In the same context, Terry Cook wrote an article entitled "The Impact of a US war on Iraq's civilian infrastructure" that examines the effects of war on the decline of Iraqi civil infrastructure. Cook notes that such a decline has initially gone back to the extensive damage inflicted in the 1991 USled Gulf War and years of UN sanctions, then followed by the 2003 invasion of Iraq. It seems that a U.S. military assault on the Iraqi infrastructure aims to establish its dominance over the country to overcome resistance and to fuel a rebellion against Saddam Hussein's regime. In the same vein, Boston Globe correspondent Anthony Shadid clarifies that the first days of U.S. air strikes on Iraq have destroyed its overwhelmed infrastructure, severing power to hospitals and 
water treatment plants, cutting off drinking water to millions in Baghdad and possibly elsewhere, and pouring raw sewage into the street within hours. Shadid also emphasizes that civilian infrastructure has suffered from the lack of maintenance and investment (qtd. in Cook). Turner continues:

You will hear the RPG coming for you

Not so the roadside bomb

There are bombs under the overpasses in trashpiles, in bricks, in cars.

Parachute bombs and artillery shells sewn into carcasses of dead farm animals.

Graffiti sprayed onto the overpasses:

I will kill you, American. (11-14, 17-20)

In the preceding lines, Turner still captures the tragic moments of the soldiers in extremis. They are chased by the unexpected ways of killing by the bombs which are sewn into the dead bodies of animals. Turner's usage of "Graffiti" is a political significance of revolution against the occupation for those who are not able to articulate their thoughts. Again, Turner's usage of that symbol refers to the deep hatred towards the presence of the colonizing forces as Iraqis can 
endure painful death by suicide attacks to liberate their country:

Men wearing vests rigged with explosives

walk up, raise their arms and say Inshallah. (21-22)

In the next lines, Turner asserts that the sacred lives of human beings are sold at a fixed price in Iraq as the murder and killing have been a source for earning living for many Iraqis. Therefore, Turner reveals the dreadful conditions of the American soldiers who have just become a target in a killing game:

There are men who earn eighty dollars

to attack you, five thousand to kill. (23-24)

As a result, the American soldiers have become suspicious of innocent people, such as small children, old men and women who offer tea (chai), for fear of being killed and their body being danced over:

Small children who will play for you,

old men with their talk, women who offer chaiand any one of them

may dance over your body tomorrow (25-28)

Finally mentioned, although that poem is characterized by the lack of Turner's emotional and reactive power, he is accused of the racist stereotypes of the Arabs as deceptive and barbaric as he depicts them deceiving their enemies and dancing over their bodies.

In Turner's poem, "The Mutanabii Street Bombing," he reveals the intangible concept of land. He emphasizes the 
interrelatedness between the cultural degradation of the natives and their devastated land. At the beginning of his poem, Turner describes a fateful day experienced by Iraqis who suffer from the scourge of war:

In the moment after the explosion, an old man staggers in the cloud of dust and debris, hands pressed hard against bleeding ears as if to block out the noise of the world at 11:4,0 A. M., the broken sounds of the wounded rising around him, roughened by pain. (1-6)

In the preceding lines, Turner refers to the manifestations of ecological ruin. He depicts the image of an old Iraqi man who teeters in the dilapidation of his ravaged country which is surrounded by "the cloud of dust and debris"(2). That old man tries hard to block his ears to avoid hearing the horrendous sounds of the explosion and injuries. That image is symbolically resonant as it signifies the old man's trial to alienate himself from his local environment that reflects his inability to inarticulate with. He just lives as a degraded prisoner destined to be killed. Turner continues:

Buildings catch fire. Cafes.

Stationary shops. The Renaissance Bookstore.

A huge column of smoke, a black anvil head

pluming upward, fueled by the Kitah al-Aghani, al1sfahani's Book of Songs, the elegies of

Khansa, the exile poetry of Youssef and al-Azzawi, religious tracts, manifestos, transaltions 
of Homer, Shakespeare, Whitman, and Nerudathese book-leaves curl in the fire's blue-tipped heat, and the long centuries handed down from one person to another, verse by verse, rise over Baghdad. (7-18)

As has already been established, Turner lays emphasis on the role of land in making the socio-cultural history of the colonized countries. Turner's approach is earlier supported by Amilcar Cabral who argues that "culture plunges its roots into the physical reality of the environmental humus in which it develops, and it reflects the organic nature of the society, which may be more or less influenced by external factors" (43). Emphasizing that approach, Turner declares that the eradication of the culture and identity of the 'Orient' (Iraqi people) is largely combined with the devastation of their physical environment.

In the preceding lines, Turner revives the rich cultural history of Iraq, reminding the colonizers of its remarkable identity. Then, he investigates the ruin of the cultural and historical buildings of Iraq, such as "buildings," "cafes," "stationary shops" and "Renaissance Bookstore" which is enriched with the books of the "Kitah al-Aghani [sic]," "Allsfahani's Book of songs," "the elegies of Khansa" and "the exile poetry of Youssef and Al-Azzawi," in addition to the "religious tracts" and "manifestos." Turner also mentions that such a bookstore includes foreign "transaltions of Homer, Shakespeare, Whitman and Neruda." These translations 
emphasize the cultural diversity of Iraq and its openness to the world. Turner's usage of the extended metaphor in the action of burning the valuable historical books symbolizes that Iraq's culture and history is under erasure. "Baghdad" has been designated as being afflicted with ruin to emphasize that colonizers have intentionally resulted in the substantial loss of the cultural and historical heritage of the Arabs; they have destroyed the capital of Iraq that is considered the most cultural and intellectual center in the Arab world. 


\section{Works Cited}

Antoon, Sinan. "Embedded Poetry: Iraq; Through a Soldier's Binoculars." Jadaliyya, 11 June. 2014,www.jadaliyya.com/Details/30803. Accessed 23 Mar. 2019.

Cook, Terry. "The Impact of a US war on Iraq's civilian infrastructure." World Socialist Web Site, The International Committee of the Fourth International, 4 November. 2002, www.wsws.org/en/articles/2002/11/iraqn04.html. Accessed 27 Mar. 2019.

Gokay, Bulent. "You can't explain the Iraq War without talking about Oil." n.p, Jul 9, 2016, www.businessinsider.com/you-cant-explain-the-iraq-warwithout-talking-about-oil-2016-7. Accessed 20 Mar. 2019.

Memmi, Albert. The Colonizer and the Colonized. London, Beacon Press, 1991.

Mukherjee, Upamanyu Pablo. Postcolonial Environments-Nature, culture and the contemporary Indian 
Novel in English, New York, PALGRAVE MACMILLAN, 2010 .

Nelson, Jake Robert. "For a Postcolonial Ecocritical Approach to International Relations." Transatlantic Perspectives on Diplomacy and Diversity, edited by Anthony Chase Feb, 2015, pp. 139-150. humanityinaction,www.humanityinaction.org/knowledge_d etail/for-a-postcolonial-ecocritical-approach-tointernational-relations/. Accessed 10 Jan. 2019.

Turner, Brian. Here, Bullet. New York, Alice James Books, 2005.

---. Phantom Noise. New York, Alice James Books, 2010.

---. My Life as a Foreign Country, New York, W.W. Norton \& Company, October 5, 2015. 